\title{
READING ON NAUSEA AND THE IMMORALIST THROUGH EXISTENTIALISM
}

\author{
Diva Wenanda \\ Universitas Trunojoyo Madura \\ e-mail:divawenanda@yahoo.com
}

\begin{abstract}
The concept of existentialism is that the existence of a person is prior to their essence. The term "existence precedes essence" subsequently became a maxim of the existentialist movement. Put simply, this means that there is nothing to dictate that person's character, goals in life, and so on; that only the individual can define their essence. This study discussed existentialism in Nausea by Jean Paul Sartre and The Immoralist by Andre Gide, through Roquentin and Michel as the Characters. Roquentin and Michels, they tend to have an absolute freedom, means there is no influence from outside. What they actually want sometimes lies no motives why they are doing that thing.
\end{abstract}

Keywords: existence, essence, existentialism. 


\section{INTRODUCTION}

Existentialism is primarily a reaction against the traditional philosophical approach to an objective and abstract understanding of human behavior. Existentialism, on the other hand, places existence before essence. Existentialist differs the term existence and essence. Existence is an actual, happens inside of the time and space. Existentialist confirms that existence has a verbal word "to exist" which means being alive, and it is merely pointing to the word of "to live". For instance, man exists (is born) before he can be anything before he can become anything, therefore his existence precedes his essence. His state of existence precedes his state of becoming. An individual is responsible for making himself into an essence, of lifting himself beyond the level of pure existence. This is where choice and action come in. people do exist means they stand in their own way as if they are out of themselves and all the things around them are connected to them. They realize that exist and free to determine the condition they desire. Roquentin in Nausea and Michel in The Immoralist are chosen to be discussed through existentialism perspective.

\section{RESEARCH METHODS}

The require data to arrange the study is found in books and references which available in the library. To do this research is known as library research, it means the writer conducts a reading process. The data consist of main data and additional data. The main data are taken from Nausea and The Immoralist. The additional data are taken from reference books, essays, criticism. The research instrument of this study is the writer, as Bogdan and Biklen argued, the researcher is the key of instrument (27).

\section{DISCUSSION}

Nausea is opened by an "Editor's Note" and the pages are presented format. The Editors suggest that Roquentin began his diary in January 1932, following his return from the Far East, Central Europe, and North Africa. He hopes that a diary will help him better understand what is going on. Roquentin realized that something strange has happened to him but soon he begins to worry that he is the one who has changed little by little. To avoid his worry, he does a research on the Marquis de Rollebon, a mysterious aristocrat who lived around the time of a French Revolution but unfortunately, he cannot help but look at himself in the mirror, signed he does not recognize his own face. In overcoming his anxiety he exclaims in his diary: "Things are bad? Things are very bad". He finds no longer recognizes people but only sees hands, eyelids, hair, cheeks, dirty skin and "enormous nostril" (45). Roquents also listens to his favorite music in a café but he still does not know what to do with himself. At the library, he also runs into the Self-Taught Man, who thinks that he can learn all there is to know by reading the entire contents of the Bouville library. It reminds him that traditional definition of time has become meaningless to him under the influence of the Nausea: "I can no longer distinguish the present from the future"(51). This part addresses the question of time and free will. Roquentin realizes that he has been studying the past to give meaning to his presence, but when he discovers that his research about Rollebon is meaningless and nothing more than educated guessing, he tries to find a purpose to his life in the present. Unfortunately, the presents are just as a glance at the past. 
Roquentin finds himself unable to complete his research on the Marquis de Rollebon. He turns his attention to women. He tries to cuddle Francois under a café table but is thoroughly disgusted by the idea of sex. He imagines ants and other vermin crawling her leg, while a sudden attack of the Nausea makes him want to vomit. Roquentin relationships with women also reveal a number of Sartre's ideas about existence. It is proven by the idea that Roquentin often evokes and describes dirty body parts and especially dirty genitalia to confront him with the disgusting nature of existence. His description of dirt and vermin seem hiding the essences, or characteristics of objects. When he touches a dirty object he is disgusted by the sensation of the objects" "existence" rather than the physical characteristics that make up its essence.

Roquentin finally sees what has been making him worry and bothering him, the meaning of his existence. He actually uses the Marquis de Rollebon to hide from his own life in the present, he tries to deny his own existence by living second-hand through Rollebon. He realizes that the past is meaningless and he must also accept reality of his existence in the present. Unfortunately, when he does this, he actually finds nothing and makes him disappointed to know that this "nothingness" is the meaning what he has been looking for so long. He endlessly repeats the Phares "I exist" to show that he can stop existing even he wants to.

After abandoning his research, Roquentin plans to visit his ex-lover in Paris. He and Anny meet as Planned but they are very awkward around each other. Anny calls Roquentin, her milestone which claims that she needs him to remain the same so Anny can tell how she has changed over the years. Anny is obsessed with the past and she also speaks of "perfect moments". Realizing that they both cannot be together, Roquentin feels very lonely especially when he walks around the city streets, but he feels comfort from his awareness of existence (73). Here, Sartre uses final section to demonstrate the inability to justify one's existence through the existence of another person. It happens when he discover the futility of the emerging of the Marquis de Rollebon. When Anny calls him "milestone" it is actually the idea how Anny wants Roquentin stays the same so she can measure her own changes. Here, Anny also questions her essence and existence just as Roquentin does. Anny has the freedom to create her own essence, means also she can define herself to anything without any measurement or standards. The conversation between Anny and Roquentin also emphasizes the failure of the past to provide a justificationthe one's existence. Roquentin cannot easily remember what free had had unlikeAnny does. It makes Roquentin easy to feel free to live in the present, unconstructed by things he has done in the past. By making Roquentin her "milestone"Anny tries to live in the past by pretending that time has had no effect on him. As Roquentin says later that Anny is a "dead women".

As it is largely discussed the term of existentialism in Nausea, it also exists in the Immoralist., the main character, Michel has done in his life. From the moment when makes a choice, he is committed. A man should not regret what he has done because an act is an act. It happens to Michael in The Immoralist who realizes who he is actually. The story is within a frame of narrative which the main body of the Immoralist is a first-person narrative from the point of view of Michel. Michel opens his story by addressing his three listeners as "My dear friends" informing them that he is a point of crisis and he is going to tell them the story of his life (7). Since it focuses on the internal life and development of the individual, stressing thoughts, emotions, and character over plot and external event, it emphasis that actually Michel is existed 
in his true life and standing on what he thinks right and Michel experiences of personal rebirth which is characterized by an increased awareness of his physical being. As he explains, "the only way I could pay attention to anything was through my five senses" (23). It indicates of Michel's growing self-awareness and lust for life. Once when he spends time in Paris with his wife, he makes no mention whatsoever of any smells odors or fragrances whether good or bad. It represents Michel's feeling of sensory deprivation while in the city, where he finds the social atmosphere stifles his discovering for natural, physical experiences. On the other hand, when he returns to La Moriniere in the spring, he again feels strong. It reveals what is called by selffreedom.

Michel's illness forces him out of his dualism between mind and body, he claims he does not have the strength to lead a dual life, and that he would think about the life of the mind later. When he is better, he abandons intellectual activity and begins a willful and organized program to strengthen his body and overcome his illness.

Both Nausea and The Immoralist try to convey what is actually existentialism. Sartre believed that humans were fundamentally free to do whatever they wanted. Rouqentin continuously states that he just wants to be free and so Michel is. Roquentin's desire to be free and self-sufficient provokes him to abandon his research on the Marquis de Rollebon and Michel tends to leave her wife alone and often goes out to seek what he actually wants to feel. Roquentin's rejection of the past causes him to embrace his existence in the present, he constantly repeats "I exist" and mocks the people of Bouville who refuse to recognize their own existence. While Michel in The Immoralist feels he has "rebirth" and thus he feels free and he actually exists and he is quite responsible with what he already committed.

It is again strengthening what has been discussed previously that the term of existentialism is clearly related to humanism theory yet it is not placing human as the highest position of all but rather locate human who is exist. Existentialism by Sartre has its own strengths what is called humanism. Delineations of Existentialism in Nausea and The Immoralist may appear in several ways. Firstly, people as the human who have consciousness. People are responsible to do what they do. In doing their duties they are not driven by other people, they are free to overreact to what they are heading to. It also proves that people are a dynamic human who always does activities and connected to other relations which exist. People are growing, changing, and having purposes. A conscious person is that who are aware of what he is doing otherwise he is thing. Secondly, freedom and responsibility to himself. Roquentin and Michel are the examples of persons who finally find their true freedom. It remains the concepts of human free will, human nature is chosen through life choices, a person is best when struggling against their individual nature, fighting for life, again, their fights might influence other people, none is independent, decisions are not without stress and consequences, there are things that are not rational, personal responsibility and discipline is crucial. Society, is unnatural and its traditional religious and secular rules are arbitrary, worldly desire is futile. Existentialism is the search and journey for true self and true personal meaning in life. 


\section{CONCLUSION}

Existentialism is also having its weaknesses and it should highlight and merely suggested to be always taken into account. Regarding the Roquentin and Michels, they tend to have an absolute freedom, means there is no influence from outside. What they actually want sometimes lies no motives why they are doing that thing. The last but not at least, the rejection of God has created for them is another problem. Sartre thinks if the God exists, He may destroy human freedom. This destroys individualism and makes a person become whatever the people in power desire thus they are dehumanized and reduced to being an object. And again, existentialism insists on the uniqueness of individuals.

\section{REFERENCES}

Bogdan,C. Robert and Biken, Knopp.(1982) Qualitative Research for Education: An Introduction to Theaory and Methods. Allyn and Baco Inc.

Gide, Andre (2000) The Immoralist. Penguin Books

Hagberg, (2010) A Companion to the Philosophy of Literature. Blackwell Publishing Ltd

Sartre, Jean Paul (2000) Nausea. Penguin Books , (2007) Existentialism is a Humanism, Yale University Press

Yussafina, Diana Mella (2015) Existentialism Jean Paul Sartre dan Relevansinya dengan Moral Manusia. UIN Semarang 